\title{
Effects of landscape spatial heterogeneity on dryland restoration success. The combined role of site conditions and reforestation techniques in southeastern Spain
}

\author{
Effets de l'hétérogénéité spatiale du paysage sur la restauration \\ de zones sèches. Rôles combinés des conditions locales \\ et des techniques de reboisement dans le sud-est de l'Espagne
}

\author{
H. KRIBECHE ${ }^{1}$, S. BAUTISTA ${ }^{1,2}$, E. CHIRINO², A. VILAGROSA², V. R. VALLEJO² \\ 1. Ecology Department - University of Alicante (Spain) \\ 2. Centro de Estudios Ambientales del Mediterráneo (CEAM) (Spain) \\ E-mail: haroun.kribeche@ua.es
}

\begin{abstract}
In occidental Europe, Spain is one of countries the most severely affected by desertification (Arnalds \& Arsher 2000). Particularly, South-eastern Spain is considered as one of the most threatened areas by desertification in Mediterranean Europe (Vallejo 1997). In 2003, the Valencia Regional Forest Service implemented a restoration demonstration project in this area. The project site is a small catchment (25 ha) located in the Albatera municipality. The catchment is highly heterogeneous, with terraced slopes, south-facing slopes and north-facing slopes. The restoration strategy was based on planting evergreen trees and shrubs which can grow quickly after disturbances, and on field treatments aimed at maximizing water collection (micro-catchments, planting furrows), organic amendment (compost), and conservation (tree shelters, mulching). On south landscape unit, the whole category of restoration treatments was applied: water micro-catchment + Tubex tree shelters + mulching \& compost, while on north landscape unit: netting tree shelters + mulching \& compost only were applied, while in terrace landscape unit: furrows + netting tree shelters + mulching \& compost were applied. Survival and growth of the planted seedlings were used as metrics of restoration success. To assess the effects of the treatments
\end{abstract}

Keywords: Mediterranean semiarid Matorral, restoration treatments, water micro-catchment \& furrows, mulching \& compost, plant shelters, soil conservation. applied for soil conservation, soil loss rates (from 2005 to 2009) were evaluated using the erosion pin method. We conclude that, despite the limiting conditions prevailing on the south unit, this landscape unit showed the highest survival and growth plant rates in the area. The best seedling performances on the south landscape unit were probably due to the highest technical efforts applied, consisting in the water micro-catchment installation and the Tubex plant shelters addition. In addition, soil loss rates followed decreasing trends throughout the assessment period. Soil loss rates were highest on south landscape unit in comparison with the other landscape units, due to the more accentuated relief. North landscape unit and terrace unit showed a net soil mass gain, probably reflecting the trapping of sediments produced by plantation works.

\section{Résumé}

La désertification est un phénomène mondial (Arnalds \& Arsher 2000). En Europe occidentale, l'Espagne est le pays le plus sévèrement touché. Particulièrement, le sud-ouest de l'Espagne est considéré comme l'une des zones les plus désertifiées de l'Europe méditerranéenne (Vallejo 1997). En 2003, le service forestier régional de Valence a exécuté un projet d'aménagement forestier expérimental dans cette zone. La zone d'étude est un bassin versant (25 ha), localisée dans la commune d'Albatera, Espagne. Le bassin versant est très hétérogène, constitué de trois unités environnementales : une zone en 
terrasses, un versant sud (adret) et un versant nord (ubac). La stratégie de restauration écologique adoptée dans cette étude est basée sur l'introduction des plantules forestières d'arbres et d'arbustes qui se caractérisent par une croissance rapide après perturbation, et de l'application d'actions de restauration écologique visant à optimiser les ressources hydriques (micro-bassins, sillons de plantation), I'amendement organique au sol (compost), la conservation de plantes (protecteurs de plantules) et la préservation des sols (paillage). Dans l'unité sud nous avons appliqué l'ensemble des traitements de préparation du terrain pour la plantation (micro-bassins + protecteurs de plantules Tubex + paillage et compost), pour l'unité nord nous n'avons appliqué que les protecteurs de plantules en maille + paillage et compost. Par contre, pour l'unité de terrasses, nous avons appliqué les sillons de plantation + protecteurs de plantules en maille + paillage et compost. La survie et la croissance en hauteur des plantes introduites sont utilisées comme des paramètres métriques pour l'évaluation du succès de restauration. Afin d'évaluer l'effet de ces actions de restauration sur la conservation des sols, nous avons mesuré des taux d'érosion (de 2005 à 2009) en utilisant la méthode des clous d'érosion. Malgré les conditions bioclimatiques limitantes présentes dans l'unité sud, celle-ci a enregistré les pourcentages de survie des plantes et les croissances en hauteur les plus élevés. Les meilleurs résultats obtenus dans l'unité sud pour la survie et la croissance en hauteur des plantules sont probablement causés par les efforts techniques appliqués, et qui consistent dans l'installation de micro-bassins et l'application de protecteurs de plantules Tubex. Généralement, les taux d'érosion ont suivi une tendance décroissante durant la période de suivi ; les taux les plus élevés sont observés dans l'unité sud, principalement dus aux propriétés topographiques très accidentées de cette unité. Les unités expérimentales nord et de terrasses ont eu un gain de la masse du sol, qui reflète probablement l'accumulation des sédiments causée par la plantation.

\section{Introduction}

Mediterranean ecosystems have undergone millenaries of land use changes, in which anthropogenic disturbances were the fundamental elements in explaining actual landscapes (Naveh 1990). Most Mediterranean mountains were intensively exploited in the past; their natural vegetation was completely eliminated for agriculture, fire wood, or for extracting ligneous substances. These intensive land uses during many decades, caused high losses in the ecosystem global biodiversity, that could be irrecoverable because of the disappearance of the original vegetation cortege in these degraded zones (Maestre et al. 2004; Bonet \& Pausas 2004).

The severe climatic conditions in these areas of the semi-arid Mediterranean basin under anthropogenic pressure make them very vulnerable to disturbances, slowly converting them to advanced desertification. These degraded areas may not recover because the original vegetation assemblages disappeared from the surroundings (Maestre et al. 2004; Bonet \& Pausas 2004) and because irreversibility thresholds have been passed (Cortina \& Vallejo 1999; Reynolds et al. 2005; Cortina et al. 2006). This disquieting environmental problem has become a major issue that requires important attention. The aggravation of this gravitational and intensive land degradation forced scientists to explore the true causes of land degradation, to develop prevention strategies aimed at reaching ecological rehabilitation of the degraded ecosystems (Rubio \& Recatalá 2006; Bautista et al. 2010).

In Mediterranean Europe, south-eastern Spain is considered to be one of the areas most threatened by desertification, due to intensive land use, land abandonment, and the currently limited bioclimatic conditions (Vallejo 1997). Within the framework of the management of Mediterranean mountains and of ecological restoration to fight against the desertification of degraded areas, a demonstration project was implemented by the Valencia Regional Forest Service in a semi-arid catchment from Albatera municipality having as main objective the reforestation of abandoned mountains in order to prevent common landscape degradation by rainstorms; avoiding inundations and its repercussions on soil loss and runoff events. In this ecological restoration demonstration project, the more innovating techniques were applied, owing to the wide reforestation experience and the range of restoration assessment studies realised in Spain.

First of all, a selection of the highest technology for plant production under the best nutrient conditions was adopted to increase plant survival and growth as well as to strengthen their resistance to cold, droughts, and entomological infections (Planelles et al. 2001; Carrasco et al. 2001). Also, the production of evergreen seedlings under dry conditions is a natural way to facilitate the plants adaptation to the harsh semi-arid bioclimatic conditions 
of the study zone. For this reason, a long container design was used in order to drive the root zone growth towards deep soil horizons (Chirino et al. 2008). In order to dig planting holes, a retro-spider digger was used facilitating soil enrichment in the soil inferior horizons (MacDonald et al. 1998; Vincent \& Davies 2003), without affecting the interplanting hole areas. In addition, Wetzel \& Burgess (2001) affirmed that soil removal during hole digging increases the concentration of nutrients in plant leaf tissues. After that, other restoration techniques of dry lands around the world were applied to optimise water storing (Ojasvi et al. 1999; Li et al. 2008; Rehman et al. 2009; Previati et al. 2010). Consequently, in the Mediterranean semi-arid reforestation projects, forest managers started to install the water micro-catchments around the planting holes to collect runoff and direct it towards the plant (Albaladejo \& Díaz 1990; Roldán \& Albaladejo 1994). Also, the application of mulch and compost to the plant was adopted due to their positive effect in the preservation of soil moisture in root zone, the reduction of rain splash impact, and for the organic amendment, particularly in areas characterised by water deficiency and eroded soils (Weill et al. 1990; Unger et al. 1991; Bautista 1999; Vincent \& Davies 2003; Agassi et al. 2004; Kruse et al. 2004). Finally, a netting and Tubex plant shelters were added to the seedlings with the aim to reduce plant exposure to the sun radiation and to protect them against rodent predation (Carreras et al. 1997; Fuentes et al. 2004).

Also, adaptive restoration is an innovative notion which appears recently in the management of degraded ecosystems. This branch of ecological restoration is based on choosing the adequate restoration treatments adapted to the characteristics of each landscape unit in the target to-be-restored area. Restoration treatments were attributed to each landscape unit depending on the severity of landscape degradation. The most degraded sites of the landscape were called the vulnerable points, where special interventions were required in order to mitigate the highest degradation processes. Furthermore, vulnerability of degraded ecosystems is considered as a key concept for the prevention and protection against any type of degradation form. Therefore, the diagnostic of vulnerable points of the degraded landscape is the correct strategy of rehabilitation. However, it is considered an initial step to restore these sensitive points to reach the rehabilitation of the whole target area. The spatial heterogeneity of the vegetation cover and of environmental factors is one of the principal characteristics of arid and semi-arid landscapes (Schlesinger \& Pilmanis 1998; Breshears et al. 1998). Therefore, at the time of making decisions about the choice of adequate land management actions, this typical attribute of spotted terrestrial ecosystems was taken into account (Tongway et al. 2004).

After ecological restoration takes place, restoration success has to be evaluated by a simple, practical, and precise monitoring. For this purpose Aronson \& Le Floc'h (1993) have developed a practical and useful approach based on the "Vital Ecosystem Attributes (VEA)" criteria. In this study, we opted to use plant performances and soil loss rates as quantitative indicators in order to evaluate the efficiency of restoration treatments. Also, we assumed that those indicators determined the success or the failure of the whole restoration demonstration project, reflecting the degree seedling establishment and soil conservation against hydric erosion. The restoration treatments used here could be useful for degraded areas characterized by the same bio-physical properties.

The hypothesis of the present work is that the restoration treatments applied to fight against desertification according to the spatial heterogeneity and vegetation distribution in the area could ensure on the short-term: 1) better establishment of introduced plants (i.e. better survival and growth rates), 2) better soil conservation and thus a decrease in soil loss rates.

\section{Materials and Methods}

\section{Study site}

Covering 24.52 ha, the study area is a subwatershed localised in the Vinalopó-segura catchment in Albatera municipality in the south of Alicante province, S.E. of Spain (long. between 00'54'35.7" 00'55'15.7' 'W, lat. between $\left.38^{\circ} 14^{\prime} 16.5^{\prime \prime} 38^{\circ} 13^{\prime} 31.8^{\prime \prime} \mathrm{N}\right)$. The high point of the sub-catchment is the Monte Alto, $682 \mathrm{~m}$ of altitude. The study site vegetation is composed of Matorral and scattered patches of Pinus halepensis forest. The Matorral is mainly composed of: Pistacia lentiscus L., Stipa tenacissima L., Juniperus 
oxycedrus L.., Rhamnus lycioides L., and Quercus coccifera $\mathrm{L}$. The Pinus halepensis Mill. patches date from the seventies reforestation projects. This watershed is one of the most severely eroded areas of all European natural areas, and is the most vulnerable to desertification risk in the north of the Mediterranean basin (Vallejo 2003). In the seventies, the last anthropogenic impact on this zone is the abandonment of cultivated terraces and the installation of water canalization across the whole catchment which removed soils and eliminated native vegetation.

The area is in the semi-arid, meso-thermic ombro-clima situated in the Thermo-Mediterranean superior bioclimatic zone, with an annual mean temperature of $19^{\circ} \mathrm{C}$ and annual rainfall of $286 \mathrm{~mm}$. It is characterised by a long dry period extending from March until October ( 7 months). The precipitations are irregularly distributed and present an elevated inter-annual variability.

The main site soil types are Humic Leptosol, Lithic Leptosol, Endopetric Calcisol, Calcic Kastanozems, and Calcaric Fluvisol, in accordance to FAO taxonomy (FitzPatrick 1980). The marl limestone soils are characterised by a high susceptibility to be degraded by hydric erosion.

\section{Restoration strategy}

The adopted restoration strategy in this demonstration project consisted of 1) planting 18 species of evergreen trees and shrubs which usually re-establish well after disturbances, and 2) applying restoration treatments

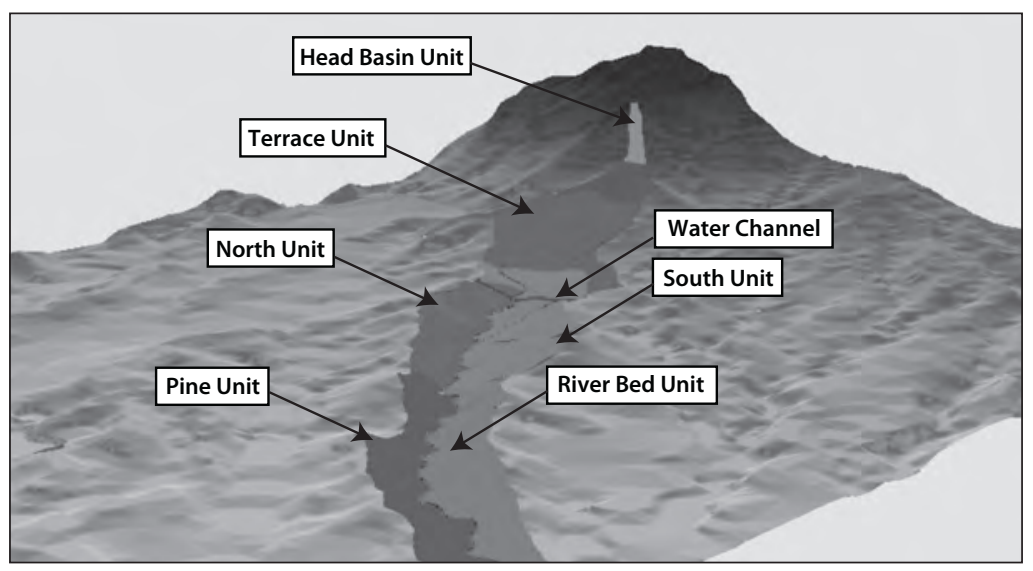

Figure 1 - Terrestrial Digital Model of the reforested sub-catchment in Albatera municipality (Alicante, Spain), delimitating the seven landscape units; the results of the three main units only were used for this paper: North, South, and Terraces units. (Source: CEAM elaboration, 2003). aiming at the improvement of conditions for plant establishment. The choice of adequate species and relevant restoration treatments depended on each of the delimited landscape units of the reforested catchment. According to the homogeneity in conditions of topography, soils, vegetation, degradation degree, and slope-facing, seven landscape units were delimited: River Bed, Water Channel, Head Basin, Pine, South, North, and Terrace units (Figure 1).

In total, more then 7868 seedlings were planted in the entire study catchment. The distribution of planted seedlings was designed to encompass their physiological properties and the edaphic and topographic conditions of the catchment. In the "River Bed unit" hygrophyte vegetation species such as: Tamarix africana Poirot, Retama sphaerocarpa, and Nerium oleander were planted. Those last three species are often associated with hot and dry climates and grow in wet soils. In the "Water Channel unit": Salsola oppositifolia, Lygeum spartum L., Nerium oleander, Rhamnus lycioides and Quercus coccifera were planted. In the "Head Basin unit" no seedlings were planted, mainly because of slope steepness, rocky outcrops, and because the grass vegetation maintains soils in this landscape unit. We therefore did not plant any tree there because of the possible impact plantation works could induce in such topographical conditions. In the Pine unit: Chamaerops humilis, Juniperus oxycedrus L. subsp. Oxycedrus, Olea europaea L., Pinus halepensis Mill., Pistacia lentiscus L., Quercus coccifera L. and Tetraclinis articulata were planted. Data analysis focused exclusively in the three main landscape units, South, North and Terrace (Table 1), because they represent the largest units of the catchment and because they present the highest signs of soil degradation and erosion. In the three main landscape units all planted species were monitored (Table 1), but the analysis were only carried out on the growth and survival of the 4 species common to the three units: Quercus coccifera L., Olea europaea L., Pistacia lentiscus L. and Rhamnus lycioides L. Six experimental plots were delimitated in each landscape unit, each constituted of 100 plants.

In January 2003, the main landscape units of the experimental watershed were reforested, on 3 experimental plots for each landscape unit: South: S1, S2, S3, North: N1, N2, N3, and Terraces: T1, T2, T3. In January 2004, the 
Table 1 - List of species planted in the whole catchment; proportions (\%) and number of seedlings planted are given for each species.

\begin{tabular}{|c|c|c|c|}
\hline Landscape Units & Seedling species & $\begin{array}{l}\text { Proportion of } \\
\text { planted seedlings } \\
\text { for the unit (\%) }\end{array}$ & $\begin{array}{l}\text { Number } \\
\text { of planted } \\
\text { seedlings }\end{array}$ \\
\hline \multirow[t]{5}{*}{ Terraces } & Quercus coccifera & 25 & 173 \\
\hline & Olea europaea & 25 & 173 \\
\hline & Pistacia lentiscus & 25 & 173 \\
\hline & Rhamnus lycioides & 25 & 173 \\
\hline & Total & 100 & 692 \\
\hline \multirow[t]{8}{*}{ South } & Pistacia lentiscus & 16 & 843 \\
\hline & Rhamnus lycioides & 16 & 843 \\
\hline & Ephedra fragilis & 13 & 685 \\
\hline & Olea europaea var. sylvestris & 13 & 685 \\
\hline & Salsola genistoides & 13 & 685 \\
\hline & Osyris quatripartita & 13 & 685 \\
\hline & Anthyllis ternifolia & 16 & 843 \\
\hline & Total & 100 & 5,267 \\
\hline \multirow[t]{11}{*}{ North } & Pistacia lentiscus & 15 & 192 \\
\hline & Pinus halepensis & 15 & 192 \\
\hline & Tetraclinis articulata & 15 & 192 \\
\hline & Olea europaea var. sylvestris & 15 & 192 \\
\hline & Quercus coccifera & 7 & 90 \\
\hline & Ceratonia siliqua & 6 & 78 \\
\hline & Chamaerops humilis & 7 & 90 \\
\hline & Juniperus oxycedrus & 7 & 90 \\
\hline & Osyris quatripartita & 7 & 90 \\
\hline & Retama sphaerocarpa & 6 & 78 \\
\hline & Total & 100 & 1,280 \\
\hline
\end{tabular}

rest of the watershed surface was reforested resulting in 3 other experimental plots for each landscape unit: South: S4, S5, S6, North: N4, N5, N6, and Terraces: T4, T5, T6. At that point, dead seedlings from the plantation of 2003 were replaced. The monitoring of the introduced plant performances was realised in all the experimental plots of the 3 landscape units: twice a year: in early summer; just after the plant growth period (July), and in early autumn; just after the plant stress period (November). The measurements of plant survival and plant height were realised from 2003 to 2005 . In this last year plant performances were only measured in autumn 2005, therefore providing 5 sampling dates during the monitoring period: July 2003 (S1, S2, S3, N1, N2, N3, T1, T2, T3), November 2003 (S1, S2, S3, N1, N2, N3, T1, T2, T3), July 2004 (S1 to S6, N1 to N6, T1 to T6), November 2004 (S1 to S6, N1 to N6, T1 to T6), and November 2005 (S1 to S6, N1 to N6, T1 to T6).

To facilitate the establishment of the seedlings, ecological restoration treatments were applied.
Before the plantation, we adopted a seedling production protocol under recent techniques of nursery breeding, focusing on the use of long plant container in order to favour a longer root growth (Chirino et al. 2008). The introduced plants were cultivated in similar biotic and abiotic conditions to the experimental zone aiming at their adaptation to the hydrological limitation of the site, and to limit plant loss to transplantation. The creation of nursery conditions similar to the field site study was principally based on the application of nutritional substrate amendment and on the use of the hydrogel support in order to provide the best conditions of water and nutrients to the produced seedlings. The favourable edaphic conditions during seedling production were planned to have positive repercussions on plant survival and growth after transplantation (Planelles et al. 2001, Carrasco et al. 2001).

Because of a long period of sun exposure in the south landscape unit, the plant Tubex shelters which decrease between: $-50 \%$ to $75 \%$ of plant sun exposition were added to the introduced plants in order to reduce plant 
Table 2 - Main landscape units, their characteristics and the applied restoration treatments.

\begin{tabular}{|c|c|c|c|c|c|c|c|}
\hline $\begin{array}{l}\text { Landscape } \\
\text { units }\end{array}$ & $\begin{array}{c}\text { Unit } \\
\text { characteristics }\end{array}$ & \begin{tabular}{|c|} 
Plant \\
species
\end{tabular} & \begin{tabular}{|c|} 
Initial total \\
number \\
of seedlings \\
planted per unit
\end{tabular} & \begin{tabular}{|} 
Restoration \\
treatments \\
common \\
to the three units
\end{tabular} & $\begin{array}{l}\text { Specific } \\
\text { restoration } \\
\text { treatments }\end{array}$ & \begin{tabular}{|c|} 
Restoration \\
objectives \\
common \\
to the three units
\end{tabular} & $\begin{array}{c}\text { Specific } \\
\text { restoration } \\
\text { objectives }\end{array}$ \\
\hline South & $\begin{array}{l}\text { Very low plant } \\
\text { cover and } \\
\text { a few pine } \\
\text { patches } \\
\text { in the lowest } \\
\text { parts } \\
\text { of the valley. } \\
\text { Less deep } \\
\text { soils profile } \\
\text { and rocks } \\
\text { surface } \\
\text { abundance } \\
\text { high slope. } \\
\text { High exposition } \\
\text { hours to sun } \\
\text { radiation. } \\
\text { Severe soil } \\
\text { erosion } \\
\text { and elevated } \\
\text { runoff events. }\end{array}$ & $\begin{array}{l}2,3 \\
4,5 \\
6,7 \\
8\end{array}$ & $\begin{array}{l}100 \times 6 \\
\text { experimental } \\
\text { plots }\end{array}$ & \multirow[t]{3}{*}{$\begin{array}{l}\text { Seedlings } \\
\text { production } \\
\text { has been realised } \\
\text { below the higher } \\
\text { nursery protocols. } \\
\text { The opening } \\
\text { of planting } \\
\text { holes } \\
(60 \times 60 \times 60) \text {. } \\
\text { Addition } \\
\text { of organic } \\
\text { compost } \\
\text { originated } \\
\text { from urban } \\
\text { bio solid, } \\
\text { and the mulch } \\
\text { originated from } \\
\text { vegetation debris. }\end{array}$} & $\begin{array}{l}\text { Opening of water } \\
\text { microcatchments. } \\
\text { Tubex Plant } \\
\text { shelters } \\
\text { (75\% of shading) }\end{array}$ & \multirow[t]{3}{*}{$\begin{array}{l}\text { To face the harsher } \\
\text { climatic conditions } \\
\text { and surpass } \\
\text { the transplantation } \\
\text { shock. To increase } \\
\text { plant cover with } \\
\text { resprouters species } \\
\text { and improve } \\
\text { the functional } \\
\text { diversity. } \\
\text { Plant protection } \\
\text { against rodents' } \\
\text { predation. }\end{array}$} & $\begin{array}{l}\text { To optimise } \\
\text { water harvesting } \\
\text { and nutrients } \\
\text { collection } \\
\text { and reduce } \\
\text { plant hydric stress. }\end{array}$ \\
\hline North & $\begin{array}{l}\text { Abundance } \\
\text { of obligate } \\
\text { seeders } \\
\text { sub shrub } \\
\text { and shrubs } \\
\text { with the presence } \\
\text { of pine patches. } \\
\text { Moderate slopes. } \\
\text { Moderate } \\
\text { soil loss process. }\end{array}$ & $\begin{array}{l}1,2 \\
3,7 \\
9,10 \\
11,12 \\
13,14\end{array}$ & $\begin{array}{l}100 \times 6 \\
\text { experimental } \\
\text { plots }\end{array}$ & & \begin{tabular}{|l|} 
Netting \\
Plant shelters \\
(25\% of shading)
\end{tabular} & & \\
\hline Terraces & $\begin{array}{l}\text { Old, abandoned, } \\
\text { and degraded } \\
\text { Terraces. } \\
\text { Low plant cover } \\
\text { and the presence } \\
\text { of old planted } \\
\text { pines. } \\
\text { Pronounced } \\
\text { relieve } \\
\text { and high slope. } \\
\text { Severe soil } \\
\text { erosion } \\
\text { and elevated } \\
\text { runoff events. }\end{array}$ & $\begin{array}{l}1,2 \\
3,4\end{array}$ & $\begin{array}{l}100 \times 6 \\
\text { experimental } \\
\text { plots }\end{array}$ & & $\begin{array}{l}\text { Opening } \\
\text { of furrows } \\
(300 \times 60 \times 60) \text {. } \\
\text { Netting Plant } \\
\text { shelters } \\
(25 \% \text { of shading) }\end{array}$ & & $\begin{array}{l}\text { To optimise } \\
\text { water harvesting } \\
\text { and nutrient } \\
\text { collection } \\
\text { along the terrace } \\
\text { surface. }\end{array}$ \\
\hline \multicolumn{8}{|c|}{$\begin{array}{l}\text { 1. Quercus coccifera L., 2. Olea europaea L., 3. Pistacia lentiscus L., 4. Rhamnus lycioides L., 5. Ephedra fragilis, 6. Salsola genistoides, } \\
\text { 7. Osyris quatripartita Salzm., 8. Pinus halepensis Mill., 9. Anthyllis temiflora, 10. Tetraclinis articulata, 11. Ceratonia siliqua L., 12. Chamaerops humilis L., } \\
\text { 13. Retama sphaerocarpa L., 14. Juniperus oxycedrus L. subsp. oxycedrus, 15. Nerium oleander L., 16. Tamarix africana Poiret, 17. Stipa tenacisima L., } \\
\text { 18. Lygeum spartum L. }\end{array}$} \\
\hline
\end{tabular}

stress conditions as well as to avoid plant predation (Craig 2008). In North and Terrace units, plant netting shelters were added to the seedlings to protect them against plant predation. These reduced plant sun exposure between: $-10 \%$ to $25 \%$.

To optimize water resources in the South unit, water micro-catchments were digged around the plants to collect runoff close to the seedlings planting holes. In the Terrace unit, the fusion of seedling planting holes in form of long furrows, extending along the terraces surface, was a useful technique to collect runoff water, increasing wet soil area; one furrow is suitable to plant 3 or more seedlings (Jia et al. 2006).

A compost amendment originating from urban bio-solids and a mulch layer were added in the seedling planting holes of all landscape units in order to provide fertilisation and to preserve the soil from hydric erosion, respectively.

The monitoring task consisted in the assessment of both components of the ecosystem: plants and soil. Plant performance was assessed by measuring height growth rates 
and survival rates to evaluate the establishment of the introduced plants. Soil loss rates were assessed by using soil erosion pins, which were installed along the reforested catchment: 150 pins per landscape unit distributed in 3 transects of 50 erosion pins; settled perpendicularly, to the watershed contours. The installed pins were separated with a spacing of $1 \mathrm{~m}$ in the same pins' transect. The loss or the gain of soil was reflected in the increase or decrease of pin height during the period of assessment. The differences in pin heights were measured using a caliper.

Soil erosion rates were measured in July 2006, July 2007, July 2008, and July 2009.

\section{Statistic analysis}

Firstly, to analyse possible differences between the obtained plant survival rates in each landscape unit, we used the statistical analysis of survival considering time as the dependent variable and the final situation of plant: "survived" or "dead" as the independent variable.

The factor variable has 3 levels reflecting the 3 categories of the applied restoration treatments:

- water micro-catchment + Tubex tree shelters on the South unit;

- without water micro-catchment + netting tree shelters on the North unit;

- furrows + netting tree shelters on the Terraces unit.

That factor variable allows us to compare between the introduced seedlings from the 3 landscape units.

To analyse plant height growth rates in each landscape unit along the time of monitoring, we run ANalyses Of VAriance (ANOVA) on repeated measures to detect 1 ) differences between the 3 landscape units for the same plant species (inter-subject effect), and 2) differences between each plant species on the same unit (intra-subject effect).

Concerning soil erosion rates analysis, we also run ANOVA analyses with repeated measures of one factor to test 1) possible differences between the 3 landscape units (intersubject effect), and 2) possible differences existing in the same landscape unit during the monitoring period (intra-subject effect).

The ANOVA analyses on repeated measures of the general linear models, and the survival analysis were executed using the SPSS 15.0 statistical software.

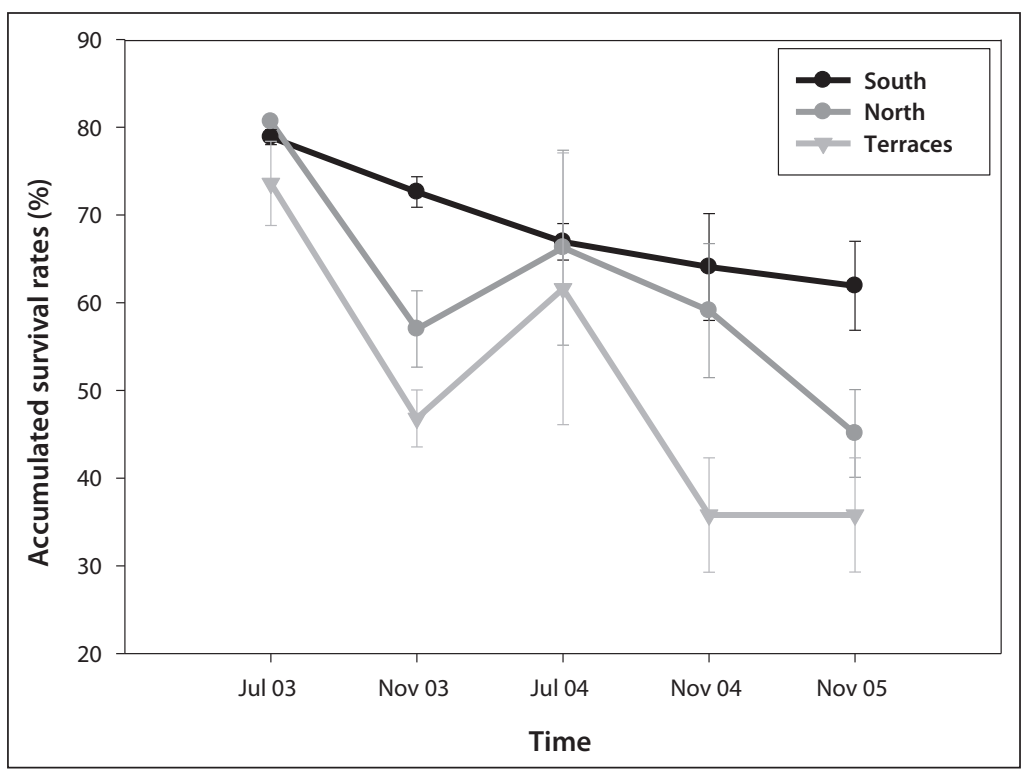

Figure 2 - Survival rates (\%) (Mean values \pm Standard error) in 3 main landscape units of the study site.

\section{Result}

\section{Effect of restoration treatments on seedling performances}

\section{Plant survival rates}

Three years after reforestation the highest accumulated survival rates $(\%)$ were obtained in the South unit with the water micro-catchments and Tubex plant shelters, while North and Terraces units had lower survival rates (Figure 2). The increased survival in July 2004 on the North and Terraces units is due to new plantings and replacement of dead individuals.

However, the survival function of the survival analysis proved that there were no significant differences between plant survival rates in the three categories of restoration treatments (significance value $=0.706$ ). On Figure 3 , the three functions corresponding to each landscape unit are almost overlapping. This means that, there were no significant differences (Wilcoxon statistic value $=0.697$ ) between landscape units. The same statistical analysis of survival testes the decreasing trend of the cumulated survival plant rates in all of the three landscape units during the monitoring period. 


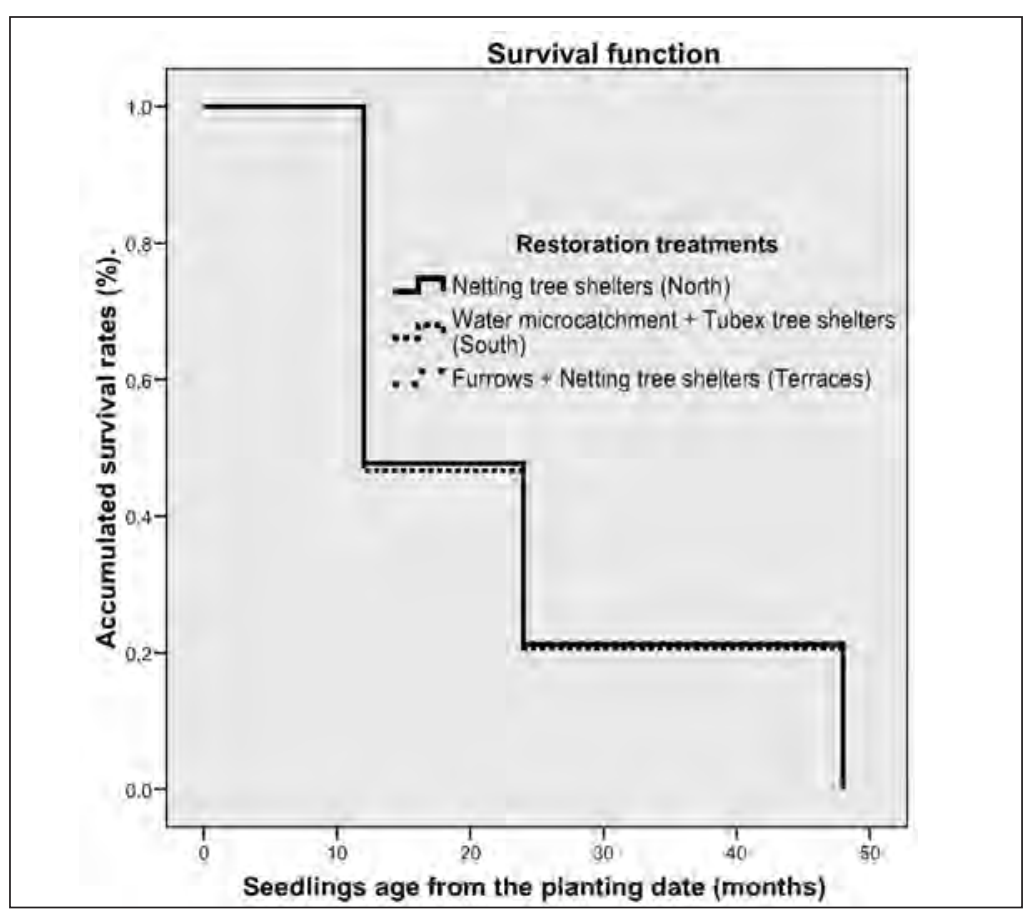

Figure 3 - Survival functions corresponding to the 3 landscape units each with specific restoration treatments (Statistical Analysis of survival. SPSS 15.0).

\section{Plant height growth rates}

The monitoring of plant growth of the 3 species; $R$. lycioides, P. lentiscus, and Olea europaea showed higher growth rates in the South landscape unit, where the water microcatchments and Tubex plant shelters were set (Figure 4). The ANOVA on repeated measures showed no significant differences in $Q$. coccifera seedling heights between the North and the Terraces units $(\mathrm{F}=3.947, \mathrm{p}=0.118)$ (Figure 4).

For Rhamnus lycioides (Figure 4), trees planted in South unit are significantly bigger than those planted in Terraces unit $(\mathrm{F}=64.020, \mathrm{p}=0.001)$.

$O$. europaea and $P$. lentiscus seedling growth was significantly better in the South unit where the water micro-catchments and Tubex plant shelters were set than in the two other units (Table 3).

P. lentiscus, O. europaea, $R$. lycioides, and $Q$. coccifera seedling's growths showed significant differences with monitoring time, for each seedling species separately and in the same landscape unit (Table 3: Monitoring time effect).

All species showed a significant effect of the interaction: "Treatment*Time of monitoring" (Table 3).

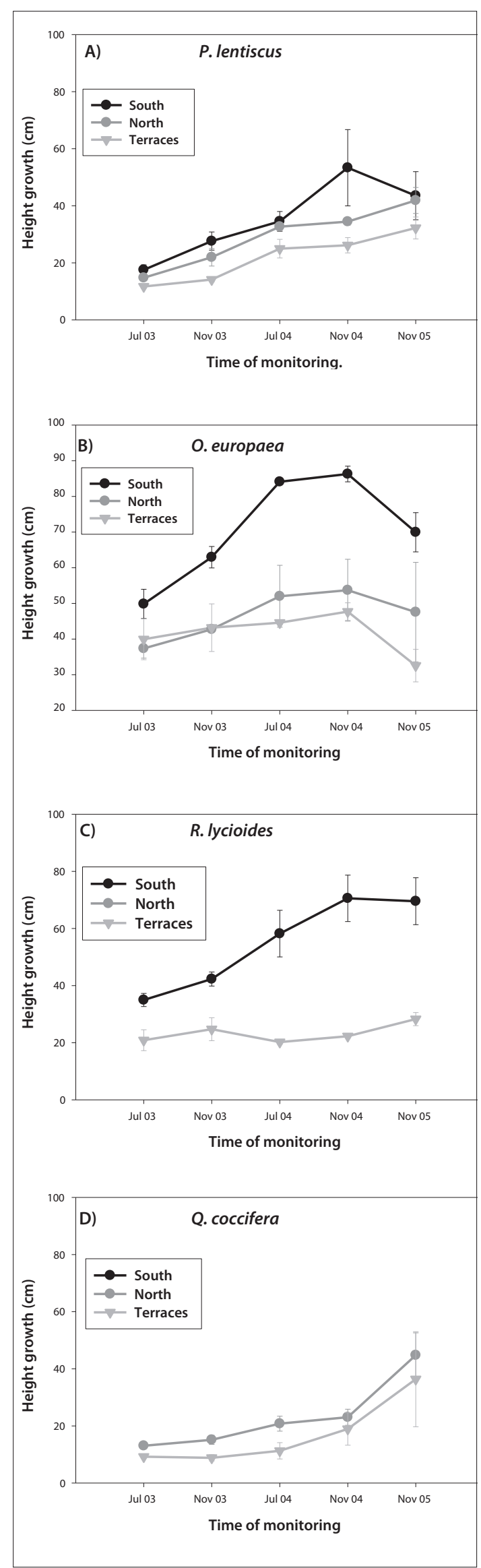

Figure 4 - Height growth rates (mean $\pm S E$ ) of P. lentiscus, O. europaea, R. lycioides and Q. coccifera seedlings in 3 main landscape units. 
Table 3 - Results of statistic analysis corresponding to 4 monitored plant species: signification $P$ and the statistical $F$ value correspondent to: inter-subject effect (effect of Treatment), intra-subject effect (monitoring time effect), and the interaction (Treatment*monitoring time effect).

\begin{tabular}{|c|c|c|c|c|c|c|c|c|c|c|c|}
\hline & & \multicolumn{8}{|c|}{ Plant height growth } & \multirow{2}{*}{\multicolumn{2}{|c|}{ Soil loss }} \\
\hline \multicolumn{2}{|c|}{ Plant species } & \multicolumn{2}{|c|}{ P. lentiscus L. } & \multicolumn{2}{|c|}{ O. europaea L. } & \multicolumn{2}{|c|}{ R. lycioides L. } & \multicolumn{2}{|c|}{ Q. coccifera L. } & & \\
\hline Statistic effect & Signification & $\mathrm{p}$ & $\mathrm{F}$ & $p$ & $\mathrm{~F}$ & $\mathrm{p}$ & $\mathrm{F}$ & $p$ & $\mathrm{~F}$ & $p$ & $\mathrm{~F}$ \\
\hline Inter-subject & Treatment & 0.008 & 12.205 & 0.009 & 11.488 & 0.001 & 64.020 & 0.118 & 3.947 & 0.303 & 1.467 \\
\hline Intra-subject & Monitoring time & 0.000 & 14.200 & 0.000 & 11.604 & 0.002 & 7.276 & 0.001 & 7.504 & 0.010 & 8.910 \\
\hline Interaction & $\begin{array}{l}\text { Treatment } \times \\
\text { Monitoring time }\end{array}$ & 0.000 & 665.843 & 0.000 & 401.966 & 0.000 & 387.986 & 0.005 & 32.467 & 0.996 & 0.000 \\
\hline
\end{tabular}

\section{Restoration treatment effect on soil conservation}

During 4 years of soil loss assessment in the 3 main landscape units there is a tendency for higher soil loss rates in the South unit than in North and Terrace units (Figure 5A). However, the ANOVA with repeated measurements showed no significant differences between soil loss rates obtained in the 3 landscape units $(\mathrm{p}=0.303, \mathrm{~F}=1.467)$.

Generally, all 3 landscape units presented a decrease trend in soil loss process during the monitoring period (Figure 5C), and a net gain soil mass was registered in the North and Terraces units (Figure 5A). The ANOVA with repeated measurements showed the significant effect of "Time of monitoring" ( $p=0.01$, $\mathrm{F}=8.910$ ), giving significant differences between soil loss rates along the monitoring period; separately and in each landscape unit.

\section{Discussion}

\section{Plant establishment}

One of the main environmental limitations for the establishment of plants in the semi-arid Mediterranean areas is the water factor (Hernandez et al. 2009). In addition to water deficiency, these degraded areas are also characterized by poor soils due to the loss of nutrients during land use pressure. Therefore, during the production of seedlings in nursery both water limitation and nutrient impoverishment had to be taken into consideration to ensure the adaptation of plants to the target reforestation area. The seedling long container design used in this reforestation project probably optimised the assimilation of water and nutrients of the introduced seedlings.
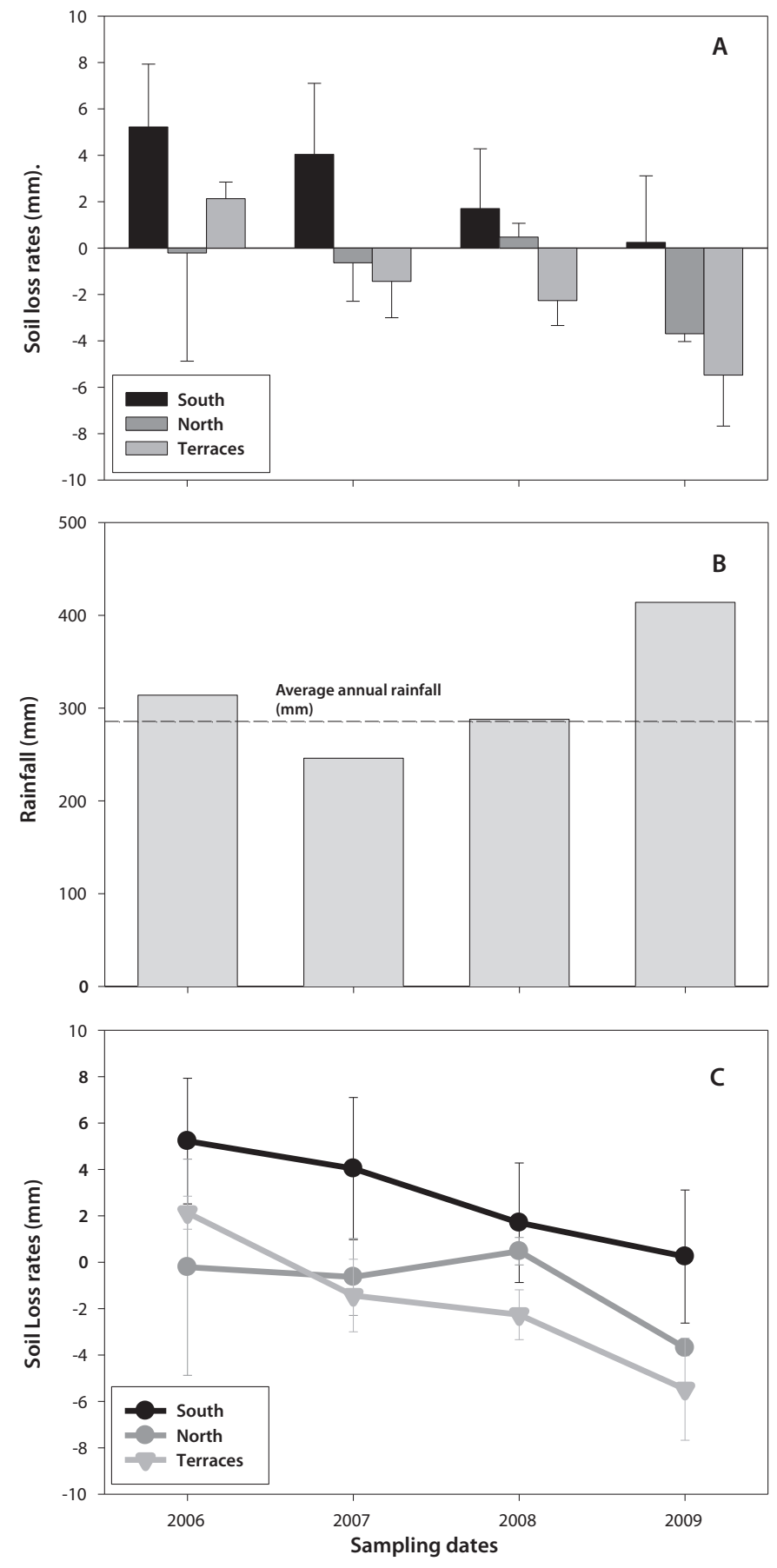

Figure 5 - A) Soil loss rates $(\mathrm{mm})$ in 3 main landscape units.

B) Rainfall (annual mean intensities) in the pilot area catchment.

C) Soil loss $(\mathrm{mm})$ trends in 3 main landscape units along monitoring period. 
It usually drives the plants to develop a deeper root system in order to survive in harsh conditions of plant water stress and nutrient soil impoverishment. The plant breeding protocol used in this study may have facilitated the successful establishment of the introduced plants, enhancing height growth rates especially in South landscape unit where survival and growth were relatively good considering the environmental conditions. The same nursery protocol probably helped to surpass the transplantation shock of the introduced seedlings, and it was reflected in the high survival rates during the first year after plantation, in all 3 landscape units. In the study of Figueroa et al. (2001) and Querejeta et al. (1998) it was confirmed that the addition of substrate amendment during seedling production in nursery increases the concentration of nutriments in plant leaf tissues. The obtained results on plant performance in the present study tend to show that the nutritional substrate applied in nursery plant protocol helped the plant establishment improving their capacity to survive in natural semi-arid conditions thus surpassing the transplantation shock.

Lloret et al. (1999) demonstrated the effectiveness of the application of sewage compost in soil fertilisation, which increased the $\mathrm{N}$ concentration in the phyto-biomass. In the same study it was also shown that the addition of mulch originating from plant debris was efficient in preserving soil moisture as well. The above demonstrations justify the use of both restoration techniques: compost and mulch in the three main landscape units of the study zone. Their application in our study zone may have contributed to improve plant performance in the limited semi-arid Mediterranean conditions.

Furthermore, it has been confirmed that the installation of water micro-catchment increases water storage, not only just after reforestation but also on the long term (Roldán et al. 1996; South et al. 2001; Whisenant et al. 1995; Yates et al. 2000). It has also been demonstrated that water harvesting techniques such as water micro-catchments provided water collection in planting holes thus increasing plant survival rates (Martínez de Azagra \& Mognil 2001; Fuentes et al. 2004). According to Carreras et al. (1997), the use of plant shelters provides better survival and growth rates to introduced plants. Furthermore, in the present study, the best survival rates took place in the first year after plantation, probably reflecting the effect of restoration treatments as: water microcatchment and Tubex plant shelters, above of all in the South unit where the severest biotic and abiotic conditions were present.

Taking into consideration the parameters above mentioned proved to be successful in this study showing short term signs of landscape restoration: transplantation shock was overcome by the introduced plants, and plant survival rates stabilized the third year after plant transplantation in two landscape units. The accumulative efficiency of restoration treatments probably improved their success, above of all in South landscape unit where the water-micro catchment and Tubex plant shelters were set, in spite of the more severe abiotic conditions on this unit, which was characterised by accentuated slopes and elevated proportion of rocks and long period of sun exposure.

Concerning plant height growth, the South landscape unit significantly registered, the best growths in comparison with the two other landscape units, also, reflecting the positive effect of the restoration treatments applied in this landscape unit.

Moreover, the significant increase in plant height growth of all species, separately and in each landscape unit, throughout the assessment period may show the accumulative effect in time of the techniques used for site preparation, and their compatibility with landscape heterogeneity (edaphic, topographic, hydric, and vegetation distribution of semi arid ecosystems). In addition, the selection of native species for the reforestation might be the correct decision which played an important role in achieving the obtained plant performance, in a pressured area of the Mediterranean semiarid such as the study zone.

\section{Soil conservation}

Site preparation is a crucial and very decisive factor at the moment of reforestation. The adequate method for digging planting holes provides minimum soil removal, and vegetation preservation against compressing and trampling, and could favour a stable soil support to introduce evergreen plants, and minimises different soil loss processes (Roldán et al. 1996; Querejeta et al. 2001; Vincent \& Davies 2003). This planting method taking into account soil and vegetation traits may have facilitated the establishment of intro- 
duced plants in the reforested area, probably due to the improvement of soil physical properties such as soil aeration and porosity, resulting in better water infiltration and soil respiration (Grantz et al. 1998; Castillo et al. 1997; Benabdeli 1998). In the present ecological restoration study innovated techniques were applied which conserve soil against erosion factors, providing minimum soil removal during the planting holes opening by the retro-spider digger.

Furthermore, water storing infrastructures were installed in the site restoration: microcatchments and furrows were installed taking into account the typical climatic features of the degraded area. The adequate dimension of these infrastructures also had to be determined to avoid its dragging by runoff flux, and to take the most of low precipitation and resist rainstorm events (Martínez de Azagra \& Mognil 2001; Navaro et al. 2001). When digging the planting holes, the adequate dimension for bare soil areas was fixed giving way to the most efficient patch/inter-patch structure which aimed at the optimisation of water and nutrient harvesting (Martínez \& Mognil 2001).

The application of the above best techniques of restoration ecology used in semi arid conditions probably enabled us to obtain those decreased trends in soil loss process in the 3 landscape units over the monitoring period. Despite the effectiveness of the applied restoration treatments in soil preservation, it was only after 4 years that the decrease trend in soil loss rates began to be noticed. This soil loss diminution in all landscape units is an indicator which proves the success of reforestation project in conserving soils. It also reflects the role of the plantation work and the applied restoration techniques in trapping sediment from upslope areas. It should also be mentioned that, in spite of the similar size and intensity of planting holes digging in the three main landscape units, it is evident that the highest soil erosion rates obtained in South unit were influenced by the unit properties, principally, the lowest vegetation cover and severe slopes.

\section{Conclusions}

The monitoring task carried out in the demonstration project of ecological restoration detected a successful establishment of introduced plants and the reduction of soil erosion. Both achievements were considered as positive signs of the restoration action effectiveness. In degraded areas of the Mediterranean basin, the preservation of soil against erosive process and the reestablishment of vegetation cover are considered two main accomplishments because of the poor recovery potential and the elevated risk of soil loss that characterise those pressured areas.

\section{Acknowledgements}

We thank all scientific, forest, and administrative entities who made possible the execution of the demonstration project of Albatera (S.E. of Spain). The project has been announced by the "Dirección General para la Biodiversidad" (Ministerio de Medioambiente-España), and It has been realised by the "Servicio Forestal de Alicante". The scientific monitoring had been realising by "Centro de Estudios Ambientales del Mediterráneo" (CEAM), Ecology department of the University of Alicante, and "Centro de Investigaciones sobre DEsertificación" (CIDE) of "Consejo Superior de Investigaciones Cientificas" (CSIC). We acknowledge financial support from Ministerio de Educación y Ciencias of CODEX-R and TRESECO projects, and Ministerio de Medio Ambiente y Medio Rural y Marino of ESTRES project. Our gratefulness to "Fundación Biodiversidad" (FUNDIVFOR project), Consolider INGENIO program (GRACIE project). Also we thank VEARSA Company and TRAGSA Holding for their collaborations in the realisation of the project. We thank infinetely Mr: Issam Touhami for his appreciable contribution in the collection of soil erosion data. We thank infinitely Ms; Darie Georgiana for the linguistic revision of the present manuscript. We are also grateful to Editor Dr. Thierry Dutoit and the anonymous reviewer for constructive comments and suggestions. 


\section{References}

Agassi M., Levy G.J., Hadas A., Benyamini Y., Zhevelev H., Fizik E., Gotessman M. \& Sasson N., 2004. Mulching with composted municipal solid wastes in central Negev, Israel: I. effects on minimizing rainwater losses and on hazards to the environment. Soil \& Tillage Research 78: 103-113.

Albaladejo J. \& Díaz E., 1990. Soil degradation and Rehabilitation in Mediterranean Environmental Conditions. CSIC, Murcia, Spain: 191-214.

Arnalds Ó. \& Archer S., 2000. Rangeland desertification. Kluwer Academic Publishers, The Netherlands press, $219 \mathrm{p}$.

Aronson J. \& Le Floc'h E., 1996. Vital landscape attributes: missing tools for restoration ecology. Restoration Ecology 4: 377-387.

Bautista S., 1999. Regeneración post incendio de un pinar (Pinus halepensis, Miller) en ambiente semiárido. Erosión del suelo y medidas de conservación a corto plazo. $\mathrm{PhD}$ Thesis. University of Alicante, $249 \mathrm{p}$.

Bautista S., Orr B.J., Alloza J.A. \& Vallejo V.R., 2010. Evaluation of the restoration of dryland ecosystems in the northern Mediterranean: Implications for Practice. Chapter 18. In: Courel M.-F. \& SchneierMadanes G. (eds), Water in Arid and Semi-arid Zones. Advances in global change research. Springer, Dordrecht, The Netherlands: 295-310.

Benabdeli K., 1998. Premier résultat dendrométrique des plantations de pin d'Alep (Pinus halepensis Mill.) dans le Barrage Vert (zone d'Aflou, Algérie), Ecologia Mediterranea 24 (1) : 43-51.

Bonet A., Pausas J.G., 2004. Species richness and cover along a 60-year chronosequence in old-fields of southeastern Spain. Plant Ecol. 174: 257-270.

Breshears D.D., Nyhan J.W., Heil C.E. \& Wilcox B.P., 1998. Effects of woody plants on microclimate in semiarid woodland: Soil temperature and evaporation in canopy and inter-canopy patches. International Journal of Plant Sciences 159: 1010-1017.

Carrasco I., Peñuelas J.L., Benito L.F., Villar-Salvador P., Dominguez S., Herrero N., Castillo V., Martínez M. \& Albaladejo J., 2001. Runoff and soil loss response to vegetation removal in a semiarid environment. Soil Sci. Soc. Am. J. 61: 1116-1121.

Carreras C., Sánchez J., Reche P., Herrero D., Navarro A. \& Navio J.J., 1997. Primeros resultados de una repoblación mediante siembra con protectores. En: Vélez Rubio. (ed.), Cuadernos de la SECF 4: 135139.

Castillo V., Martínez M. \& Albaladejo J., 1997. Runoff and soil loss response to vegetation removal in a semiarid environment. Soil Scs. Soc. Am. J. 61: 1116-1121.

Chirino E., Vilagrosa A., Hernandez E.I., Matos A. \& Vallejo R.V., 2008. Effects of a deep container on morpho-functional characteristics and root colonization in Quercus suber L. seedlings for reforestation in Mediterranean climate. Forest Ecology and Management 256: 779-785.

Cortina J., Maestre F.T., Vallejo V.R., Baeza M.J., Valdecantos A. \& Pérez-Devesa M., 2006. Ecosystem structure, function, and restoration success: Are they related? Journal for Nature Conservation 14: 152160.

Cortina J. \& Vallejo V. R., 1999. Restoration of Mediterranean ecosystems. In: Farina A. (ed.), Perspectives in Ecology. A glance from the VII International Con- gress of Ecology. Backhuys Publishers, Leiden: 479-490.

Craig S., 2008. Protecting trees and shrub from deer. NRCS: USDA Natural Resource Conservation Service-North Dakota: 1-4.

Figueroa D., Barea J.M., Viedma A. \& Martínez-Fernández J.F., 2001. Crecimiento y asimilación de nutrientes en cuatro especies arbustivas, sometidas a micorrización y adición de composta en condiciones semiáridas. Actas del III Congreso Forestal Español. Granada, España 6: 573-578.

FitzPatrick E.A., 1980. Soils: Their formation, classification and distribution. University of Aberdeen. Published in the United States of America by Longman Inc, New York: 156-157.

Fuentes D., Valdecantos A. \& Vallejo V.R., 2004. Plantación de Pinus halepensis Mill. y Quercus ilex subsp. Ballota (desf) samp. en condiciones Mediterráneas secas utilizando microcuencas. Cuad. Soc. Esp. Cien. For. 17: 157-161.

Grantz D.A., Vaughn D.L., Farber R.J., Kim B., Ashbaugh L., VanCuren T., Campbell R., Bainbridge D. \& Zink T., 1998. Transplanting native plants to revegetate abandoned farmland in the western desert. J. Environ. Qual. 27: 960-967.

Hernández E.I., Vilagrosa A., Luis V.C., Llorca M., Chirino E. \& Vallejo V.R., 2009. Root hydraulic conductance, gas exchange and leaf water potential in seedlings of Pistacia lentiscus L. and Quercus suber L. grown under different fertilization and light regimes. Environmental and Experimental Botany 67: 269-276.

Jia Y., Li F.M., Wang X.L. \& Yang S.M., 2006. Soil water and alfalfa yields as affected by alternating ridges and furrows in rainfall harvest in a semiarid environment. Field Crops Research 97: 167-175.

Kruse R., Bend E. \& Bierzychudek P., 2004. Native plant regeneration and introduction of non-natives following post-fire rehabilitation with straw mulch and barley seeding. Forest Ecology and Management 196: 299-310.

Li X.Y., Zhao W.W., Song Y.X., Wang W. \& Zhang X.Y., 2008. Rainfall harvesting on slopes using contour furrows with plastic-covered transverse ridges for growing Caragana korshinskii in the semiarid region of China. Agricultural Water Management 95: 539-544.

Lloret F., Casanovas C. \& Puñelas J., 1999. Seedlings survival of Mediterranean species in relation to root: shoot ratio, seed size and water and nitrogen use. Functional Ecology 13: 210-216.

MacDonald S.E., Schmidt M.G. \& Rothwell R.L., 1998. Impacts of mechanical site preparation on foliar nutrients of planted white spruce seedlings on mixed wood boreal forest sites in Alberta. Forest Ecology and Management 110: 35-48.

Maestre Gil F.T., Cortina i Segarra J. \& Gil Polo F., 2004. Repoblaciones de «Pinus halepensis» y restauración de ecosistemas en medio semiárido. Cuadernos de la Sociedad Española Ciencias Forestales 17: 181-186.

Martinez de Azagra A. \& Mognil J., 2001. Algunos criterios para el diseño de sistemas de recolección de agua en repoblaciones forestales. In: Junta de Andalucia-S.E.C.F. (eds). Actas del III Congreso Forestal Español. Sevilla, España 2: 272-277.

Martínez J.F., González G., Alvarez J., Bago D. \& Castillo V., 2001. Crecimiento en repoblaciones de Pinus halepensis Mill. en medios semiáridos: el 
efecto de los tratamientos de suelo y planta está influido por la variabilidad ambiental. Actas del III congreso forestal nacional. Granada, España 3: 255262.

Navaro F.B., Ripoll M.A., Bocio I. \& de Simón E., 2001. Importancia de la vegetación natural en la forestación natural en la forestación de tierras agrarias de zonas semiáridas: respuesta a los procedimientos de preparación de suelo. Actas del III congreso forestal nacional. Granada, España 3: 292297.

Naveh Z., 1990. Fire in the Mediterranean - A landscape ecological perspective. In: Vallejo V. R. (ed.), La restauración de la cubierta vegetal en la comunidad Valenciana. Fundación Centro de Estudios Ambientales del Mediterráneo, Valencia. Fundación CEAM: Centro de Estudios Ambientales del Mediterráneo: Modelo Digital del Terreno de la cuenca hidrográfica de Albatera, Alicante (España).

Ojasvi P.R., Goyal R.K. \& Gupta J.P., 1999. The microcatchment water harvesting technique for the plantation of jujube (Zizyphus mauritiana) in an agroforestry system under arid conditions. Agricultural Water Management 41: 139-147.

Planelles R., Oliet J.A., Artero F. \& Lopez M., 2001. Efecto de la distintas dosis N-P-K sobre la calidad funccional de planta de Ceratonia celiqua. Respesuta en plantaciones. Actas del III congreso forestal nacional. Granada, España 3: 599-605.

Previati M., Bevilacqua I., Canone D., Ferraris S. \& Haverkamp R., 2010. Evaluation of soil water storage efficiency for rainfall harvesting on hillslope micro-basins built using time domain reflectometry measurements. Agricultural Water Management 97: 449-456.

Querejeta J.I., Roldán A., Albaladejo J. \& Castillo V., 1998. The role of mycorrhizae, site preparation, and organic amendment in the afforestation of a semiarid Mediterranean site with Pinus halepensis Mill. Forest Science 44 (2): 203-211.

Querejeta J.I., Roldán A., Albaladejo J. \& Castillo V., 2001. Soil water availability improved by site preparation in a Pinus halepensis Mill. afforestation under semiarid climate. Forest Ecology and Management 149: 115-128.

Rehman S., Shad K.K., Amanullah A.R., Khan A.Z. \& Shah N.H., 2009. Micro-watershed enhances rain water use efficiency, phenology and productivity of wheat under rainfed condition. Soil Tillage Research 104: 82-87.

Reynolds J.F., Maestre F.T., Huber-Sannwald E., Herrick J. \& Kemp P.R., 2005. Aspectos socioeconómicos y biofísicos de la desertificación. Ecosistemas 14 (3): 3-21 http://www.revistaecosistemas.net/articulo.asp?Id=1 31.
Roldán A. \& Albaladejo J., 1994. Effects of micorrizal inoculation and soil restoration on the growth of Pinus helepensis Mill. seedlings in semiarid soil. Biol. Fertil. Soil. 8: 143-149.

Roldán A., Querejeta I., Albaladejo J. \& Castillo V., 1996. Survival and growth of Pinus halepensis Mill. seedlings in semiarid environment after forest soil transfer, terracing and organic amendments. Ann. Sci. For. 53: 1099-1112.

Rubio J.L. \& Recatalá L., 2006. The relevante and consequences of Mediterranean desertification including security aspects. In: Kepner W. G. (ed.), Desertification in the Mediterranean region: A security issue. The NATO Programme for Security through Science, The Netherlands press, $601 \mathrm{p}$.

Schlesinger W.H. \& Pilmanis A.M., 1998. Plant-soil interactions in desert. Biogeochemistry 42: 169-187.

South D.B., Rose R.W. \& McNabb K.L., 2001. Nursery and site preparation interaction research in the United States. New Forest. 22: 43-58.

Tongway D.J., Cortina J. \& Maestre F.T., 2004. Heterogeneidad espacial y gestión de medios semiáridos. Ecosistemas 13 (1): 2-15.

Unger P.W., Stewart B., Aparr J.F. \& Singh R.P., 1991. Crop residue management and tillage methods for conserving soil and water in semiarid regions. Soil Tillage Research 20: 219-240.

Vallejo V.R., 1997. La restauración de la cubierta veg etal en la comunidad Valenciana. CEAM-Generalidad Valenciana, Valencia, 601 p.

Vallejo V.R., 2003. Alertan de que el sur de Alicante es la zona Europea donde más avanza la erosión. Newspaper: Información. Digital Edition, Section: Medio ambiente.

Vincent A. \& Davies S.J., 2003. Effects of nutrient addition, mulching and planting-hole size on early performance of Dryobalanops aromatica and Shorea parvifolia planted in secondary forest in Sarawak, Malaysia. Forest Ecology and Management 180: 261-271.

Weill A.N., Mehuys G.R. \& Mckyes E., 1990. Effect of tillage reduction and fertilizer type on soil properties during corn (Zea mays 1.) production. Soil Tillage Research, 17: 63-76.

Wetzel S. \& Burgess D., 2001. Understorey environment and vegetation response after partial cutting and site preparation in Pinus strobus L. stands. Forest Ecology and Management 150: 43-59.

Whisenant S.G., Thurrow T.L. \& Maranz S.J., 1995. Initiating autogenic restoration on shallow semiarid sites. Restoration Ecology 3: 61-67.

Yates C.J., Hobbs R.J. \& Atkins L., 2000. Establishment of perennial shrubs and tree species in degraded Eucalyptus salmonophloia (salmon gum) remnant woodlands: effect of restoration treatments. Restoration Ecology 2: 135-143. 